\title{
ВПЛИВ ЦІННІСНИХ ОРІЄНТАЦІЙ НА СФЕРУ ГУМАНІТАРНОГО ПІЗНАННЯ
}

\section{Н.В. Буруковська}

Суспільство XX-XXI сторіччя характеризується наявністю транзитивних моментів у розвитку, а разом з цим неминучими $є$ протиріччя, які призводять до виникнення конфліктів. Саме в суспільстві вони виникають, отже, в суспільстві мають й вирішуватись. Головною метою в цьому процесі $є$ вирішення конфлікту та досягнення консолідуючої згоди (консенсусу). Треба відзначити, що саме в такому суспільстві на сьогодні відбувається становлення індивіда. Саме індивід є носієм соціокультурних норм та цінностей, характерних для будь-якого суспільства. Таким чином, саме в суспільстві, як в інтерсуб'єктивному горизонті життєвого світу, відбувається народження індивіда й подальша його еволюція в соціальному світі, тобто формування особистості як носія найвищих цінностей.

Цінності та ціннісна свідомість відіграють значну роль в житті людського співтовариства. Вона полягає в тому, що ціннісна свідомість, тобто усвідомлені та засвоєні індивідом соціальні цінності, виступають механізмом, який забезпечує інтеграцію індивідуальних людських дій в єдину цілісну систему соціальної взаємодії, регламентує засоби задоволення потреб, регулюючи тим самим індивідуальну та групову поведінку. Адекватне розуміння природи цінностей та ціннісного усвідомлення дає можливість визначити детермінанти людської дії, виявити вплив цінностей на формування особистості в контексті соціальних відношень даного суспільства, зазначити шляхи його гуманізації. Цим і обумовлюється та велика увага, яку приділяють проблемі цінностей в науковій літературі.

Досить часто в сучасному світі людина виявляється не суб'єктом,

Актуальні проблеми духовності 
а об'єктом надособових соціальних сил, що сприяє віднесенню на периферію суспільного життя загальнолюдських цінностей. Порівняння певних процесів у філософії та теорії світового літературознавства, які виявились адекватними у своїй сутності за дослідженнями Х.Г. Гадамера, Ю. Хабермаса, М. Фуко та у творчості Г. Гесе, Дж. Джойса, Ф. Кафки, В. Набокова, свідчать про те, що не можна заперечувати «суб'єктивність» цінностей. Вони не суб'єктивні, оскільки існують незалежно від емпіричних особливостей конкретного суб'єкту; але вони суб'єктивні, оскільки існують тільки у співвідношенні з суб'єктами і завдяки їм отримують постійне відновлення. Незважаючи на постійну увагу до проблеми вивчення цінностей, багато її аспектів залишаються ще непроаналізованими.

Поняття «цінність» досить по-різному трактується дослідниками різноманітних напрямків, чим і пояснюється велика кількість дефініцій. Одна з точок зору виходить з того, що цінності розглядаються як об'єктивне благо, предмети, явища, властивості тощо, які незалежно від знання про них і відношення людини відіграють позитивну роль в їі житті. Таким чином, цінностями визнається тільки те, що об'єктивно сприяє суспільному прогресу та благу людини.

Пошук об'єктивного критерію цінного призваний протистояти аксіологічному релятивізму, однак він залишає поза сферою розгляду засіб засвоєння цінностей людиною. Очевидно, предмет лише тоді може сприйматися як цінність, впливати на вчинки індивіда, коли останній усвідомлює зв'язок його властивостей та якостей з усіма потребами та інтересами. Предмет, що володіє об'єктивною позитивною значністю, яка не відображена свідомістю людини залишає людину байдужою до нього або ж викликає дії, неадекватні реальної ролі предмета в житті людини. Регулятивні функції цінність виконує тільки тоді, коли предмет реально приваблює до себе людину, визначає цілі їі життєдіяльності, підштовхує до певних дій.

В рамках західного суспільствознавства можна умовно виділити два напрямки, які відображають подвійну природу цінностей.

Один з них характеризується психологічною інтерпретацією ціннісної свідомості. Так, на думку австрійського філософа Ф. Брентано, усі психічні феномени завжди являють собою відношення до чогось, спрямовані до деякого неявного або уявленого об'єкту. Основний вид таких відношень - це людські афективні та волютативні реакції на об'єкти, які, таким чином, і являють собою ціннісні відношення. «Стверджуючи або заперечуючи існування об'єкта або можливість такого існування, - наголошує $Ф$. Бретано, - ми схвалюємо чи не схвалюємо його, 
радіємо, сумуємо, сподіваємося, боїмося, оцінюємо його відповідним чином» ${ }^{1}$.

Найбільш цілісного вигляду вказана концепція набула в теорії американського вченого Р.Б. Перрі. «Обговорюючи дефініцію цінності, писав він, - ми будемо постійно зв'язані з моторно-афективним життям, тобто з інстинктами, бажаннями, почуттями, волею, а також 3 цілою родиною подібною до них актів, станів та установ. Тому необхідним є термін, який був би застосований до всього, що виражає цю особливість життя й свідомості, який був би достатньо широким, щоб охопити усю її різноманітність, та значення якого можна було б уточнити в ході подальшого аналізу. Термін «інтерес» являється в цьому відношенні найкращим» ${ }^{2}$.

Таким чином, під цінністю розуміється будь-який продукт будьякого інтересу, а категорія «інтерес» охоплює всю сферу емоційновольової активності індивіда.

Психологічне направлення інтерпретації цінностей акцентує увагу на з'ясуванні механізму зв'язку суб'єкта та безпосередньо цінності, але недостатньо з'ясованим залишається питання природи цього зв'язку та її обгрунтування. Цінність виявляється позбавленою залежності від власних онтологічних обгрунтувань, окрім того, її суб'єктивізація й трактовка тільки як продукту індивідуальної ціннісної свідомості ускладнює пояснення факту ціннісної єдності людей в рамках певних соціально-культурних спільностей.

В іншому ключі проблема цінностей розглядається в рамках феноменологічного напрямку. Засновник феноменології німецький філософ Е.Гуссерль розглядав оцінювання також як спрямований емоційний акт, який, однак, відрізняється від простих емоційних реакцій наявністю певного предметного змісту. В такому акті цінність розглядається як існуюча поза суб'єктом, поза його свідомістю та незалежно від них.

Розвиваючи ідеї Гуссерля, М. Гартман визначав ціннісну свідомість як апріорне емоційне спостерігання особливих ідеальних якостейцінностей. «По своєму засобу буття, — вказував М. Гартман, усі цінності являються платонівськими ідеями, метафізичними «сутностями», які порівнюються 3 логічними та математичними об'єктами» ${ }^{3}$.

Цінності, таким чином, розуміються як ідеальні, прості та незалежні одна від іншої якості, які не відносяться до емпіричного світу та

\footnotetext{
${ }^{1}$ Бабушкин В.У. О природе философского знания. Критика современных буржуазных концепций.-М.: 1978.- С. 18.

${ }^{2}$ Perry R.B. General theory of Value. - Cambridge, 1954. - P. 115.

${ }^{3}$ Гартман М. Естетика. / Переклад з нім.-M., 1958.-C. 109.
} 
розташовані в незмінному ієрархічному порядку. Специфіка ідеального буття цінностей вбачається Гартманом у тому, що самі по собі вони не здібні визначати будь-що в реальному світі, а втілюються в дійсність лише в результаті усвідомлення їх людиною та відповідною людською діяльністю.

Для цього в структуру ціннісної свідомості включається здібність до апріорного пізнання цінності, за допомогою якої схоплюється її ідеальне буття, а також до емоційного переживання цінності, втіленої в реальну дійсність. Активність ціннісної свідомості визначається тим, що вона є невід'ємною від емоційних актів, переживань, бажань, волі, за допомогою яких надчасове, надісторичне буття цінності втілюється в реальність. М. Гартман зазначав, що «... етичні цінності по силі своєї слабкіші за закони природи. Але оскільки вони визначають волю людини - вони це виконують, коли потреби етики зрозумілі людині, ïx визначаюча сила все ж таки сильніша за закони природи, остільки вони являються самими сильними принципами» ${ }^{4}$.

Феноменологічна аксіологія зафіксувала в своїх побудовах дійсну та досить важливу особливість ціннісної свідомості - глибокий внутрішній зв'язок з емоційним переживанням світу, здібність «не опосередковано», поза яких-небудь раціональних форм «схоплювати» цінність, значимість явищ. Однак, намагаючись уникнути властивого психологічним концепція суб'єктивізму, вона винесла цінності як би «за дужки» реального світу, залишивши, таким чином, без уваги питання, які пов'язані з історико-культурною специфікою розуміння самих цінностей, а також і відповідну обумовленість ціннісної свідомості.

Відмінності в філософських трактуваннях знайшли своє відображення і в соціологічних теоріях, активно вивчаючих цінності та ціннісні системи. Американський соціолог Ф. Адлер редукував більшість дефініцій цінностей, які використовують в західній соціології до чотирьох основних типів:

1. Цінності є абсолютами у вигляді Бога, вічних ідей, автономних принципів.

2. Цінності заключаються в матеріальних і нематеріальних предметах або в нерозривно зв'язаних з ними якостях чи їх атрибутах, які цінуються, бажаються, здібні задовольнити потреби.

3. Цінності заключаються в самій людині, в їі біологічних потребах та розумі.

\footnotetext{
${ }^{4}$ Там же.- C. 522 .
} 
4. Цінності ототожнюються з діями, вербальними або невербальними, і не існують ніде, окрім дії

Кожен 3 вказаних типів грунтується на реальних особливостях, властивих феномену цінності, і прагне обгрунтувати виділення саме цієї особливості в якості найбільш істотної. Виходячи з цього, особливої уваги заслуговує дефініція цінності, яку дали американські соціологи У. Томас та Ф. Знанецький. «Під соціальною цінністю, - пишуть вони, - ми розуміємо будь-який предмет, який володіє емпіричним змістом, доступним членам соціальної групи, а також значенням, внаслідок якого він $є$ або може бути об'єктом дії» ${ }^{6}$.

У такому трактуванні цінності мають певний об'єктивний зміст (правда, термін «емпіричне» значно звужує сферу дії даного визначення), який стає очевидним, актуалізується, виявляє себе як цінність тільки тоді, коли входить до сфери людської діяльності, яка має соціально-історичну природу. Таким чином, стверджується, що цінності не можна звести до психіки індивіда, але, разом з тим, їм не можна приписувати якості абсолютного об'єктивного існування, подібно якостям природних явищ, тому що цінності, будучи культурними явищами, не можуть існувати зовсім незалежно від діючих суб'єктів, а виявляються як елементи їх дій.

Поняття цінності взагалі відображає властивість вказувати на людське, соціально-культурне значення тих чи інших об'єктів, на визначеність об'єкту для суб'єкту. Цінності, засвоєні суб'єктом, є орієнтирами діяльності, факторами інтенціональності його свідомості. Система цінностей конкретного суб'єкту, обумовлена розвитком загальноісторичної практики, є найвищим ідеальним рівнем соціальної регуляції, який становить нормативний аспект свідомості. Генеза найпростіших цінностей контекстуальна, вона зумовлена взаємодією об'єктивного та суб'єктивного факторів.

Підсумовуючи вищезгадане необхідно відзначити, що природа цінності складна, багатогранна та суперечлива, чим і пояснюється наявність різноманітних підходів до її осмислення. Для цього дослідження уявляється істотним виділення двох моментів: по-перше, потенційної «здібності» об'єкту бути «цінністю», по-друге, суб'єктивного визнання значимості даного об'єкта. Потрібно також підкреслити, що сприйня-

\footnotetext{
${ }^{5}$ Adler $F$. The Value concept in sociology // American Journal of Sociology.1956. - 62, № 3. - P. 272-279.

${ }^{6}$ Ручка A.A. Ценностный подход в системе социологического знания.-К., 1987. - C. 110 .
} 
ття об'єкта як цінності визначається його природними якостями та властивостями, взятими не самі по собі, а крізь призму їх засвоєності та включення в діяльність конкретно-історичного індивіда.

Ціннісні орієнтації є феноменом соціально-культурним. Тому через персоналізацію цінностей навіть віра в якесь особисте обожнювання потребує допомоги безособових опосередкувань - понять добра, могутності, справедливості, моральних законів, духовних структур тощо. Однак цінності аж ніяк не являють собою загальну ідею. Загальна ідея - це певна сума детермінацій, сила яких в постійному відтворенні. Цінність же - це живлюще та невичерпане джерело визначень. В цьому можна вбачити більш тісну спорідненість з особистим буттям, ніж із світом всезагальностей. Найбільш обгрунтованим цінностям притаманне історичне існування. Навіть вічне, всупереч поширеному забобонові, протилежне непорушному і являється в образах, що безперервно оновлюються.

Можна казати про покликання епох та цінностей. Кожна з них народжується, розвивається, застигає в непорушності, сходить на ні. Час застою породжує всілякого роду непорозуміння. Його можна відкинути під приводом служіння йому, якщо зробити спробу закріпити його в одній із застиглих історичних форм, коли вона починає занепадати.

Невірно було б твердити або заперечувати «суб'єктивність» цінностей. Вони не суб'єктивні, оскільки існують незалежно від емпіричних особливостей даного, конкретного суб'єкту; але вони і суб'єктивні, оскільки існують тільки в співвідношенні з суб'єктами, завдяки їм отримують постійне народження, не будучи привернутими до жодного з них: цінності виступають посередниками між суб'єктами, виділяючи кожного з його самотності та сприяючи їх універсальному розвитку. Ось чому їх не можна плутати 3 проекціями «Я», які значно скоріше вичерпають свої скромні ресурси. Цінності, навпаки, свідчать про те, що особистість не лишається обмеженою та ізольованою в дійсності, прив'язаною до умов свого існування. Особистість в кінцевому підсумку - це рух до трансперсонального, про що свідчать одночасно і досвід причетності, і досвід цінності.

Кожна людина робить себе тією особистістю, якою вона стає через взаємодію з іншими в рамках інтерсуб'єктивного горизонту життєвого світу. Саме концепція самості, запропонована Ю. Хабермасом, навіть у своїй розмитій формі, обгрунтовує самоідентичність людини, в якій сама свідомість чітко виявляє себе, як етичне самоствердження відповідальної особи. Тобто, суть «індивідуальності» доречно пояснювати з позиції саморозуміння першої особи по відношенню до інших 
осіб. Тільки та особа, яка знає чим вона $є$ і чим вона хоче бути - visà-vis самої та інших - може володіти поняттям індивідуальності. Ці структури ідентичності мають бути закріплені у відносинах інтерсуб'єктивного визнання. 3 цього приводу Хабермас зазначав: «Еgо створює себе, в першу чергу, як відповідь на Alter Ego» ${ }^{7}$.

Дуже важливим фактором в зв'язку з цим рухом $є$ питання про співвідношення мови та мислення. Сприйняття світу крізь призму мови формує переконання про те, що мова створює та визначає думку. Мова не ізольований феномен, вона тісно пов'язана з культурою взагалі, це й є механізм, який породжує думку. В мові первісно закладений творчий та ціннісний потенціали. Думка проявляється крізь мову, причому кожен акт промовляння $є$ творчим процесом, в якому народжується нова істина.

Комунікативність виявляється саме суспільною природною сутністю мови. Слово є не тільки продуктом індивідуальної свідомості. Комунікативний процес діалогічний, розуміння завжди припускає непорозуміння, оскільки кожний речовий вираз суто творчий акт, який несе відбиток неповторності (в межах сучасної теорії комунікації за К.-О. Апелем - мова, дискурс - це соціальний вимір розуму; у концепції світової літератури ХХ сторіччя - Умберто Еко - слово: лабіринт та засіб для дискусіі). Комунікація, яка спрямована на порозуміння, здійснюється на основі суб'єкт - об'єктних відносин і тому потребує уваги та поваги до інших, спирається на розвинуту здатність слухати та говорити.

Спроба розглянути систему цінностей в такій сфері гуманітарного знання як теорія літератури дає можливість виокремити три визначні для неї епистеми: класичну Ренесанську, некласичну та сучасну, кожній з яких притаманна власна домінуюча система ціннісних орієнтацій.

Для класичної епістеми в літературі притаманні зовнішня положеність та обумовленість. Існуючі із давніх-давен сюжети можна використовувати тільки в чистому виді. «Я»героя не можна розуміти, як «Я» індивіда, особистості. Це складний образ, що складається протягом століть, як, наприклад, образи богатирів, князів, кобзарів, бунтарів («Слово о полку Ігореві», Гомер «Іліада», Р. Джовальоні «Спартак» і т. п.). Таким чином, Ренесанській епістемі притаманна чиста суб'єктивність, так звана рафінована раціональність. Образ героя, його

${ }^{7}$ Habermas $J$. Moralbewußtsein und kommunikatives Handeln. - Frankfurt a. M., 1983. - S. 11-12. 
«Я» несе в синкретичному вигляді сукупність цінностей, притаманних культурі епохи, які пов'язані з історичним досвідом багатьох поколінь. Домінуючу систему цінностей цього періоду можна назвати буттєвосоціальною.

Щодо некласичної епістеми світової літератури, то в текстах цього періоду з'являється герой, в «Я» якого більше індивідуального, ніж суспільного, але це суб'єктивізм прагматичної орієнтації. «Я»-«Він» (Інший) - цієї формули притримувалися автори текстів цього направлення (у Джона Апдайка в «Кентаврі» - герой - людина, як і всі інші особи, які оточують його, але він ще й кентавр, якого ніхто не розуміє, тобто він не такий, як усі інші, він Інший). Система цінностей з цієї позиції надто однобока, надто індивідуальна та особиста.

В сучасній епістемі навпаки «Я»-це «Вони» (колектив), тобто існують на світі люди, які розділяють спільну точку зору і погляди на світ, які однаково дивляться на різні речі та ситуації, їм подобаються однакові книжки, вистави, фільми тощо. Це приклад інтерсуб'єктивної раціональності. Герой вже не самотній борець за якісь ідеали, він або знає, або шукає своїх однодумців (у В.Набокова в кінці роману «Запрошення на страту» Цінцінат Ц. розуміє, що він не один, що на світі є люди, які схожі на нього, але ж до цього висновку герой приходить тільки наприкінці життя). Саме звертаючись до сучасних текстів можна стверджувати, що відбувається синтез соціальних та індивідуальних цінностей як в межах буття однієї людини, одного героя, так і на його відчуттях в межах колективного несвідомого, або навпаки на передчутті кожної особистості в кризових станах свідомості.

Контури існування такої сфери, що пов'язана із знанням свідомо-несвідомого виміру, розглядаються в дослідженнях С.К'єркегора, М.Бубера, М. Бахтіна та інших філософів, які в своїх працях розглядали феномен «Я» по відношенню до інших людських «Я».

Саме поняття «цінність» несе в собі настільки суперечливе значення, що для дослідника занадто складним виявляється контекстне дослідження методологічного потенціалу цінностей. Як правило, це потребує окремого вивчення ціннісних орієнтацій, особливо в сфері гуманітарного знання. Аксіологічні чинники, які превалюють в сфері науки, зорієнтовані перш за все на людину, їі свідомість, ідеали, внутрішні настанови. Другу хвилю аксіологічного впливу створюють соціальні пріоритети людського життя.

Отже, цінності в сфері гуманітарного знання об'єднують в собі суб'єктивні ідеали окремої людини та об'єктивні пріоритети суспільства конкретної історичної доби. 